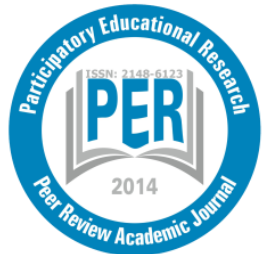

Participatory Educational Research (PER)

Vol.9(1), pp. 137-149, January 2022

Available online at http://www.perjournal.com

ISSN: 2148-6123

http://dx.doi.org/10.17275/per.22.8.9.1

\title{
The Effect of Using Web 2.0 Tools in the Primary School 4th-Grade Science Course on Various Variables
}

\author{
Mustafa Ziya Uysal ${ }^{*}$ \\ 15 Temmuz Sehitleri Primary School, Konya, Turkey \\ ORCID: 0000-0002-7785-0930
}

\author{
Barıș Çayc1 \\ Department of Primary Education, Ömer Halis Demir University, Niğde, Turkey \\ ORCID: 0000-0003-3466-7033
}

\section{Article history}

Received:

30.10 .2020

Received in revised form: 08.07.2021

Accepted:

19.07.2021

Key words:

Web 2.0 tools;

Use of animation;

Science courses
In this study, we aimed to determine the effects of Web 2.0 animation tools for science education on 4th-graders' academic achievements and basic skills, as well as their attitudes and motivations towards science courses. The study was designed with pretest-posttest control group quasi-experimental pattern. The sample consisted of 4th-grade students studying at one of the primary schools in Selçuklu, Konya, Turkey. In the comparison of the pretest mean scores of the students in the data collection tools applied to the experimental and control groups as a pretest, it was determined that the groups were equivalent to each other in terms of their baseline characteristics. The topics in the experimental and control groups were taught in accordance with the methods-techniques prepared and recommended according to the 4th grade curriculum. Unlike the students in the control group who did not receive any additional intervention, the students in the experimental group watched animations prepared by the researcher. In the posttest mean scores of the students in the experimental and control groups, there was a significant difference in favor of the experimental group ( $t(55)$ achievement $=-2.23$, $\mathrm{p}<0.05)$. Accordingly, the teaching process applied in the experimental group was more effective on academic achievement than the teaching process in the control group. In the comparison of the results of the test of basic process skills ( $t(55)$ Skill $=-.730, p>0.05)$ applied as a posttest to the experimental and control groups at the end of the teaching processes and the posttest mean scores obtained by the students in terms of their attitude ( $\mathrm{t}(55)$ attitude $=-.730, \mathrm{p}>0.05)$ and motivations ( $\mathrm{t}(55)$ motivation=.149, $\mathrm{p}>0.05)$ towards science, no significant difference was found between the groups. In this respect, the teaching processes applied to the experimental and control groups did not create any difference in the students' basic skills, attitudes or motivations towards science

\footnotetext{
*Correspondency: muysal88@hotmail.com
} 


\section{Introduction}

Today, fast-advancing technology leads to many changes in our daily lives. The acceleration of access to information not only contributes to an increase in the knowledge of societies, but it also accelerates changes in societies. "Today, in other words in age of the information society, what is expected from individuals is production, becoming practical and own the qualities of entrepreneurship" (Çötok, 2006: 53-54). In the information society that puts people in the center, human intelligence and creativity play a key role in achieving results. Thereupon, educational institutions should prepare individuals in accordance with the necessities of the time.

The term Web 2.0 was used in 1999 by Darcy DiNucci in her article "Fragmented Future". While Web 1.0 does not allow interaction and consists of only images and text, Web 2.0 is a new platform that is "readable, writable, dynamic, flexible and interactive with social applications" (Silva, Rahman and El Saddik, 2008: 9-13). Web 2.0 refers to social technological environments where users who visit content platforms can contribute to this content effectively, make additions and switch from a passive to an active position.

We are facing a generation who met technology at an early age and uses it a lot. One of the benefits of Web 2.0 tools is that they facilitate communication with this generation. Web 2.0 tools that are used effectively and at the right time facilitate the interaction of students with teachers and content and "improve students' research, inquiry and problem solving skills" thanks to cooperative learning (Özmen, Aküzüm, Sünkür and Baysal, 2011: 46). Web 2.0 tools are used for educational purposes in classroom environments thanks to their many features. Thanks to their feature of allowing the participation of multiple individuals, for instance, Web 2.0 tools provide many opportunities such as enabling individuals to socialize and focusing individuals on a common goal. The use of Web 2.0 has increased rapidly thanks to its basis of "Connect - Learn - Develop - Share". Another reason why users prefer Web 2.0 tools is that "they allow working with flexible time intervals." Additionally, "supporting users' creativity" has increased the popularity of these tools (Jarrett, 2008: 4-13).

The easy use and advantages of Web 2.0 technologies provide teachers and students with the support they need. "The usage area of second-generation web tools is expanding rapidly" (Deperlioğlu and Köse, 2010: 338). The COVID-19 pandemic has shown the world the importance of using computers and the internet in educational environments. Due to the effect of the pandemic, in Turkey, as in many countries, there has been a trend towards a combined model where face-to-face education and distance education are carried out together. Teachers use Web 2.0 tools to be able to conduct distance education and prepare effective class designs and materials. At this point, it is important that teachers are experts in their fields who are open to using new technologies, can use technology in their learning-teaching activities share their technology experiences with their colleagues and have similar qualifications.

In this study, we aimed to determine the effects of Web 2.0 animation tools for science education on 4th-grade students' academic achievements and basic skills, as well as their attitudes and motivations towards science courses. Thus, we sought answers to the following research questions:

(1) Is there a significant difference between the pretest and posttest scores of the students in the experimental group regarding academic achievement, basic skills, and attitude and motivation towards science courses? 
(2) Is there a significant difference between the pretest and posttest scores of the students in the control group regarding academic achievement, basic skills, and attitude and motivation towards science courses?

(3) Is there a significant difference between the posttest academic achievement, basic skills, attitude and motivation scores of the students in the experimental and control groups?

\section{Method}

This is a quantitative and experimental study. The design of the study included a pretest, a posttest and a control group quasi-experimental pattern. "Patterns targeting at finding cause-effect relationships between variables are called experimental designs" (Creswell, 2017: 376-418). "Experimental studies aiming to discover cause-effect relationships are studies in which the data to be examined is revealed under the control of the experimenter" (Karasar, 2000).

The pretest-posttest control group model is created by a random method. One of the subjects is randomly grouped under the experimental group, another is left under the control group, and so on. In both groups, measurements are made before and after the intervention. The presence of a pretest in this model is critical for ensuring that the groups are equivalent prior to the measurement and comparing the posttest results. After the researcher determines the experimental and control groups, the experimental procedure is applied only to the experimental group. Finally, the researcher performs the posttest application to measure the differences between the two groups (Creswell, 2017: 376-418). Table 1 shows the structure of this model.

Table.1 List of symbols representing experimental patterns

\begin{tabular}{|c|c|c|c|}
\hline GROUP & PRETEST & EXPERIMENTAL PROCESS & POSTTEST \\
\hline Experimental Group & E1, E2, E3, E4 & (Animation)-Aided & E1, E2, E3, E4 \\
\hline Control Group & E1, E2, E3, E4 & Curriculum-Based Activities & E1, E2, E3, E4 \\
\hline
\end{tabular}
E1: Academic Achievement Test for the unit of "Our Foods"
E2: Basic Skill Test
E3: Science Course Attitude Scale
E4: Science Course Motivation Scale

\section{Study Groups (Experimental and Control Groups)}

The experiment was carried out in one of the primary schools in the Selçuklu district of the province of Konya in Turkey with the permission of the Directorate of National Education (MEM). We chose the school where the study would be conducted from among alternative schools, taking into account the criteria of easy accessibility and the volunteerism of the teachers and administrators who supported the research.

In the research process, the pretests that were applied before the teaching processes were used to determine the experimental and control groups. For the design of the experimental and control groups, the pretest scales were applied to four different 4th-grade classes in the primary school where the study was carried out. "In cases where the group size is higher than 50, Kolmogorov-Smirnov test is used to examine the conformity of the data to normal distribution" (Büyüköztürk, Çokluk and Köklü, 2018: s.146). Additionally, the standard errors 
of skewness and kurtosis were used for checking normality. If the coefficients of skewness and kurtosis were in the range of \pm 1.5 , the data were considered to be normally distributed (Tabachnick and Fidell, 2013).

Based on the results of the aforementioned analyses of the collected data, parametric tests were used for the normally distributed data (See: Table-2).

Table.2 Kolmogorov-Smirnov test results and values of skewness and kurtosis

\begin{tabular}{llcccccc}
\hline & \multicolumn{3}{c}{ Kolmogorov-Smirnov } & \multicolumn{2}{c}{ Skewness } & & Kurtosis \\
& Statistic & df & Sig. & Statistic & Std. H. & Statistic & Std. H \\
\hline Motivation Scale & .080 & 109 & .084 & -.279 & .231 & -.317 & .459 \\
\hline Attitude Scale & .095 & 109 & .017 & -.326 & .231 & .337 & .459 \\
\hline $\begin{array}{l}\text { Academic Achievement } \\
\text { Test }\end{array}$ & .093 & 109 & .021 & -.030 & .231 & -.414 & .459 \\
\hline $\begin{array}{l}\text { Test of Basic Process } \\
\text { Skills }\end{array}$ & .079 & 109 & .089 & -.015 & .231 & .413 & .459 \\
\hline
\end{tabular}

The data collected from the procedures followed to determine the experimental and control groups were analyzed, and the results are given in Table 3.

Table.3 One-way ANOVA results for the analysis of the differentiation of the pretest scores of the students in the experimental and control groups according to the classes

\begin{tabular}{|c|c|c|c|c|c|c|}
\hline & \multirow[t]{2}{*}{ Groups } & \multicolumn{3}{|c|}{ Group Statistic } & \multicolumn{2}{|c|}{ ANOVA } \\
\hline & & $\mathbf{N}$ & $\bar{x}$ & SS & $\mathbf{F}$ & $\mathbf{P}$ \\
\hline \multirow[b]{4}{*}{ Motivation Scale } & Class A & 29 & 2.49 & .356 & \multirow[t]{4}{*}{2.434} & \multirow[t]{4}{*}{.069} \\
\hline & Class B & 26 & 2.48 & .293 & & \\
\hline & Class C & 27 & 2.49 & .242 & & \\
\hline & Class D & 27 & 2.32 & .193 & & \\
\hline \multirow[b]{4}{*}{ Attitude Scale } & Class A & 29 & 2.44 & .250 & \multirow[t]{4}{*}{1.628} & \multirow[t]{4}{*}{.187} \\
\hline & Class B & 26 & 2.51 & .258 & & \\
\hline & Class C & 27 & 2.48 & .231 & & \\
\hline & Class D & 27 & 2.37 & .251 & & \\
\hline \multirow{5}{*}{$\begin{array}{l}\text { Academic } \\
\text { Achievement Test }\end{array}$} & Class A & 29 & 11.65 & 2.37 & \multirow[t]{5}{*}{5.542} & \multirow[t]{5}{*}{.001} \\
\hline & Class B & 26 & 10.80 & 3.21 & & \\
\hline & Class C & 27 & 11.03 & 3.27 & & \\
\hline & Class D & 27 & 8.62 & 2.83 & & \\
\hline & & & & & & \\
\hline \multirow{4}{*}{$\begin{array}{l}\text { Test of Basic } \\
\text { Process Skills }\end{array}$} & Class A & 29 & 17.51 & 5.26 & \multirow[t]{4}{*}{2.702} & \multirow[t]{4}{*}{.049} \\
\hline & Class B & 26 & 16.53 & 4.53 & & \\
\hline & Class C & 27 & 14.55 & 4.38 & & \\
\hline & Class D & 27 & 14.77 & 3.91 & & \\
\hline
\end{tabular}

As shown in Table 3, it was found that the differences between the groups in terms of their "Academic Achievement Test" mean scores $(\mathrm{F}=5.542 ; \mathrm{p}<0.05)$ and "Basic Skills Scale" mean scores $(F=2.702 ; p<0.05)$ were significant $(p<0.05)$. Tukey's HSD test was performed to determine between which groups the significant difference was, and the results are given in Table 4. 
Table.4 One-way ANOVA results for the analysis of the differentiation of the pretest scores of the students in the experimental and control groups according to the classes

\begin{tabular}{|c|c|c|c|c|}
\hline & Group (i) & Groups (j) & $\begin{array}{l}\text { Mean Difference } \\
(\mathrm{i}-\mathrm{j})\end{array}$ & $\mathbf{p}$ \\
\hline \multirow{12}{*}{ 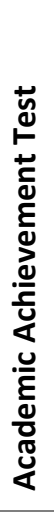 } & Class A & Class B & .84748 & .709 \\
\hline & & Class C & .61814 & .860 \\
\hline & & Class D & $3.02554^{*}$ & .001 \\
\hline & Class B & Class A & -.84748 & .709 \\
\hline & & Class C & -.22934 & .992 \\
\hline & & Class D & $2.17806^{*}$ & .040 \\
\hline & Class C & Class A & -.61814 & .860 \\
\hline & & Class B & .22934 & .992 \\
\hline & & Class D & $2.40741^{*}$ & .017 \\
\hline & Class D & Class A & $-3.02554^{*}$ & .001 \\
\hline & & Class B & $-2.17806^{*}$ & .040 \\
\hline & & Class C & $-2.40741^{*}$ & .017 \\
\hline \multirow{12}{*}{ 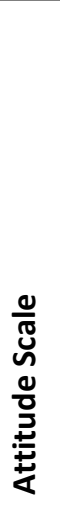 } & Class A & Class B & .97878 & .857 \\
\hline & & Class C & 2.96169 & .079 \\
\hline & & Class D & 2.73946 & .119 \\
\hline & Class B & Class A & -.97878 & .857 \\
\hline & & Class C & 1.98291 & .395 \\
\hline & & Class D & 1.76068 & .500 \\
\hline & Class C & Class A & -2.96169 & .079 \\
\hline & & Class B & -1.98291 & .395 \\
\hline & & Class D & -.22222 & .998 \\
\hline & Class D & Class A & -2.73946 & .119 \\
\hline & & Class B & -1.76068 & .500 \\
\hline & & Class C & .22222 & .998 \\
\hline
\end{tabular}

As seen in Table 4, there was a significant difference between the mean score of Class D and the mean scores of the other classes in terms of the pretest academic achievement values $(\mathrm{p}<.05)$. On the other hand, according to the results of the analysis for the basic skill pretest scores, we could not find a statistically significant difference between the classes ( $p>0.05)$.

After the data collected from the procedures followed to determine the experimental group were analyzed, it was decided to form the experimental group from among Classes A, B and $\mathrm{C}$ that were equivalent to each other. Among these three classes, 4-A and 4-B were determined by lot. Then, the lot was drawn again, and 4-B was assigned as the experimental group (26), while 4-A was assigned as the control group (29). To examine whether the groups were equivalent in more detail, the pretest data obtained from the measurement tools were analyzed by paired-samples t-test (Table 5 ).

Table.5 Paired-samples t-test results based on the pretest mean scores of the experimental and control groups

\begin{tabular}{llllllll}
\hline & $\mathrm{n}$ & $\bar{x}$ & $\mathrm{Sd}$ & $\mathrm{t}$ & $\mathrm{sd}$ & $\mathrm{p}$ \\
\hline $\begin{array}{l}\text { Academic } \\
\text { Achievement Test }\end{array}$ & Experimental Group & 26 & 10.807 & 3.212 & 1.119 & 53 & .268 \\
& Control Group & 29 & 11.655 & 2.237 & & & \\
Test of Basic & Experimental Group & 26 & 17.517 & 4.536 & .734 & 53 & .466 \\
Process Skills & Control Group & 29 & 16.538 & 5.268 & & & \\
Attitude Scale & Experimental Group & 26 & 2.515 & .258 & -1.044 & 53 & .301
\end{tabular}




$\begin{array}{llllllll} & \text { Control Group } & 29 & 2.443 & .250 & & \\ \text { Motivation Scale } & \text { Experimental Group } & 26 & 2.482 & .293 & .106 & 53 & .916 \\ & \text { Control Group } & 29 & 2.492 & .356 & & \end{array}$

The results of the paired-samples t-test indicated that there was no statistically significant difference between the experimental and control groups based on their pretest scores of academic achievement, basic skills, attitude and motivation. These results revealed that the two groups were equivalent to each other.

\section{Teaching Process}

The unit titled "Our Foods" in the science course took six weeks (18 class hours) to teach in the two groups. In the experimental group, the classes were held by the researcher, while in the control group, the classes were held by the students' own teacher. During the research process, before the science classes, the researcher and the other teacher communicated about the activities to be performed in the classes. The experimental group's classes were supported by animations that were prepared by the researcher using the PowToon animation tool. The control group's classes were carried out by their own teacher in accordance with the methods-techniques prepared and recommended according to the 4thgrade curriculum of the Turkish Ministry of National Education (MNE). The students in the experimental and control groups performed activities recommended in the 4th-grade curriculum. Unlike the students in the control group, the students in the experimental group watched the animations prepared by the researcher.

Before conducting the study, the targeted achievements of the "Our Foods" unit in the Science Course curriculum were examined to prepare the animations to be used in the experimental group, and within the framework of these targeted achievements, animations suitable for the MEB textbook were created.

\section{Data Collection Tools}

In this study 'the Academic Achievement Test for the Unit of Our Foods', 'the Basic Skills Scale' and 'the Science Course Attitude and Motivation Scales' were utilized for the pretest and the posttest. Prior to the experimental procedure, for pilot implementation purposes, the scales were tested by applying them to 126 fifth-grade students from two secondary schools in the Selçuklu district of Konya.

\section{Academic Achievement Test}

This test was prepared to measure the academic success levels of the students in the "Our Foods" unit of the science course within the scope of which the research was conducted. The Academic Achievement Test for the Unit of Our Foods consisted of 20 questions, each question had four options, and the test measured the levels of the participating students regarding the targeted academic achievements in the 4th-grade unit 'Our Foods'. The test was analyzed in terms of its validity and reliability and made ready for application. In the development of the questions in the test, the topics in the "Our Foods" unit of the 4th-grade science textbook were examined, and questions were created in proportion to the weights of these topics in the curriculum. For the test reliability, the KR-20 coefficient was calculated as 0.82. A measurement instrument is considered reliable based on the lowness of its random errors. The reliability index takes values ranging from "0" to "1" (Turgut and Baykul, 2011, 
p.123). The KR-20 reliability coefficient obtained in this study indicated that the test prepared for the implementation was quite reliable.

\section{Test of Basic Process Skills}

Adapted by Aydoğdu and Karakuş from the original scale developed by Padilla, Cronin and Twist, the "Test of Basic Process Skills" was used in this study to quantify the participants' basic scientific process skills. The scale consists of 31 multiple-choice questions. This test evaluates six basic process skills: measuring, observing, predicting, classifying, communicating and inferring. Using the data obtained from the pilot implementation, the KR20 reliability coefficient of the scale was calculated as 0.94 .

\section{Attitude Scale}

The "Science Course Attitude Scale" that was developed by Uyanık (2014) was used to measure the 4th-grade students' attitudes towards the science course. This 3-point Likerttype ("Never", "Sometimes", "Always") scale consists of 18 items. Based on the experimental results, it was identified that the scale has two factors. Three of the 18 items (M13, M10, M3) in the attitude scale were excluded from the scale because the factor loads of each of these items under two different factors were close to each other. The reliability analysis of the scale in the final form determined the reliability coefficient (Cronbach $\alpha$ ) to be 0.94.

\section{Motivation Scale}

The "Science Course Motivation Scale" that was developed by Uyanık (2014) was used to measure the 4th-grade students' motivation towards the science course. This 3-point Likert-type ("Never", "Sometimes", "Always") scale consists of 19 items. Based on the data obtained from the pilot implementation, it was identified that the scale has two factors. Item M3 in the motivation scale was excluded from the scale since it had similar factor load values under two different factors. The reliability analysis of the scale in the final form determined the reliability coefficient (Cronbach $\alpha$ ) to be 0.94 .

\section{Data Analysis}

The SPSS 15.0 software was used for statistical analysis. The data obtained from the experiment were determined to be normally distributed, and thus, parametric tests were used to analyze the test and scale scores. In the study, paired-samples t-test and independentsamples t-test were used in addition to one-way analysis of variance (ANOVA). When the ANOVA produced significant differences, Tukey's HSD tests were also used to identify the sources of the differences. In the analysis, $\mathrm{p}<.05$ was considered statistically significant.

\section{Results}

\section{Results for the First Research Question}

In the study, the first research question was: "Is there a significant difference between the pretest and posttest scores of the students in the experimental group regarding academic achievement, basic skills, and attitude and motivation towards science courses?" Table 6 shows the paired-samples t-test results based on the pretest and posttest mean scores of the experimental group regarding their academic achievement, basic skills, attitude and motivation for science courses. 
Table.6 Paired-samples t-test results based on the pretest posttest mean scores of the experimental group

\begin{tabular}{llllllll}
\hline & $\mathrm{n}$ & $\bar{x}$ & $\mathrm{Sd}$ & $\mathrm{T}$ & $\mathrm{sd}$ & $\mathrm{p}$ \\
\hline $\begin{array}{l}\text { Academic } \\
\text { Achievement Test }\end{array}$ & Pretest & 26 & 10.807 & 3.212 & 4.117 & 25 & .000 \\
& Posttest & 26 & 16.076 & 2.910 & & & \\
Test of Basic & Pretest & 26 & 16.538 & 4.536 & 1.261 & 25 & .219 \\
$\begin{array}{l}\text { Process Skills } \\
\text { Attitude Scale }\end{array}$ & Posttest & 26 & 17.653 & 4.766 & & & .234 \\
& Pretest & 26 & 2.515 & .258 & 1.219 & 25 & .383 \\
Motivation Scale & Posttest & 26 & 2.600 & .333 & & & .25 \\
& Pretest & 26 & 2.482 & .293 & .278 & 25 & .783 \\
& Posttest & 26 & 2.495 & .347 & & & \\
\hline
\end{tabular}

Based on the academic achievement test scores presented in Table 6, the difference between the pretest and posttest scores of the experimental group was significant $(t=4.11, p<0.05)$. While the pretest mean scores of the students in the experimental group was $\bar{X}=10.807$, their posttest mean score was $\bar{X}=16.076$ in posttest, where the difference $\left(\bar{X}_{\mathrm{ST}}-\bar{X}_{\text {Ö }}=5.269\right)$ indicated a higher academic achievement level in the posttest. Accordingly, the Web 2.0 animation activities were academically effective in the science courses.

Based on the results demonstrated in Table 6, the intervention in the experimental group positively affected the students' posttest scores regarding their basic skills, attitudes and motivation, but this increase was not statistically significant. As such, in the experimental group, the effect of animation-aided teaching on the pretest-posttest scores regarding basic skills $(\mathrm{t}=1.26, \mathrm{p}>0.05)$, science course attitude $(\mathrm{t}=1.21, \mathrm{p}>0.05)$ and motivation $(\mathrm{t}=0.27$, $\mathrm{p}>0.05)$ was not statistically significant.

\section{Results for the Second Research Question}

The second research question was: "Is there a significant difference between the pretest and posttest scores of the students in the control group regarding academic achievement, basic skills, and attitude and motivation towards science courses?" Table 7 shows the paired-samples t-test results based on the pretest and posttest mean scores of the control group regarding their academic achievements, basic skills, attitudes and motivations.

Table.7 Paired-samples t-test results based on the pretest and posttest mean scores of the control group

\begin{tabular}{|c|c|c|c|c|c|c|c|}
\hline & & $\mathrm{n}$ & $\bar{x}$ & sd & $\mathrm{t}$ & sd & $\mathrm{p}$ \\
\hline \multirow{2}{*}{$\begin{array}{l}\text { Academic } \\
\text { Achievement Test }\end{array}$} & Pretest & 29 & 11.655 & 2.379 & \multirow[t]{2}{*}{5.170} & \multirow[t]{2}{*}{28} & \multirow[t]{2}{*}{.000} \\
\hline & Posttest & 29 & 14.069 & 3.663 & & & \\
\hline \multirow{2}{*}{$\begin{array}{l}\text { Test of Basic } \\
\text { Process Skills }\end{array}$} & Pretest & 29 & 17.512 & 5.268 & \multirow[t]{2}{*}{2.089} & \multirow[t]{2}{*}{28} & \multirow[t]{2}{*}{.046} \\
\hline & Posttest & 29 & 19.000 & 5.230 & & & \\
\hline \multirow[t]{2}{*}{ Attitude Scale } & Pretest & 29 & 2.443 & .250 & \multirow[t]{2}{*}{1.722} & \multirow[t]{2}{*}{28} & \multirow[t]{2}{*}{.096} \\
\hline & Posttest & 29 & 2.537 & .297 & & & \\
\hline \multirow[t]{2}{*}{ Motivation Scale } & Pretest & 29 & 2.492 & .356 & \multirow[t]{2}{*}{.315} & \multirow[t]{2}{*}{28} & \multirow[t]{2}{*}{.755} \\
\hline & Posttest & 29 & 2.515 & .426 & & & \\
\hline
\end{tabular}


Examining the data on the academic achievement test $(\mathrm{t}=5.17, \mathrm{p}<0.05)$ and the basic skills test $(\mathrm{t}=2.08, \mathrm{p}<0.05)$ displayed in Table 7 , the difference between the pretest and posttest scores of the control group was significant. While the academic achievement pretest mean score of the students in the control group was $\bar{X}=11.655$, their mean score increased to $\bar{X}=14.069$ in the posttest. The difference was in favor of the posttest $\left(\bar{X}_{\mathrm{ST}}-\bar{X}_{\mathrm{O}} \mathrm{T}=2.414\right)$. While the basic skill pretest mean score of the students in the control group was $\bar{X}=17.512$, their mean score increased to $\bar{X}=19.000$ in the posttest. The difference was in favor of the posttest ( $\bar{X}_{\mathrm{ST}}-$ $\bar{X}_{\text {ӧт }}=1.488$ ). Accordingly, the activities performed in the control group in the scope of the routinely applied curriculum and without any additional intervention were effective on the students' academic achievement and basic skills.

According to the data in Table 7, the routinely applied curriculum practices positively affected the students' attitudes and motivation posttest scores in the control group, but the increases did not have statistical significance. In this context, the effect of regular curriculum activities used in the control group on the students' pretest and posttest scores in science course-related attitudes $(t=1.72, p>0.05)$ and motivations $(t=0.31, p>0.05)$ was not statistically significant.

\section{Results for the Third Research Question}

The third research question was: "Is there a significant difference between the posttest academic achievement, basic skills, attitude and motivation scores of the students in the experimental and control groups?" Table 8 shows the independent-samples t-test results based on the posttest mean scores of the experimental and control groups regarding their academic achievements, basic skills, attitudes and motivations.

Table.8 Independent-samples t-test results based on the posttest mean scores of the experimental and control groups

\begin{tabular}{|c|c|c|c|c|c|c|c|}
\hline & & $\mathrm{n}$ & $\bar{x}$ & $\mathrm{sd}$ & $\mathrm{t}$ & sd & $\mathrm{p}$ \\
\hline $\begin{array}{l}\text { Academic } \\
\text { Achievement Test }\end{array}$ & $\begin{array}{l}\text { Experimental } \\
\text { Group } \\
\text { Control Group }\end{array}$ & 26 & 16.076 & 3.663 & -2.233 & 53 & .030 \\
\hline $\begin{array}{l}\text { Test of Basic } \\
\text { Process Skills }\end{array}$ & $\begin{array}{l}\text { Experimental } \\
\text { Group } \\
\text { Control Group }\end{array}$ & 26 & 17.653 & 4.766 & .994 & 53 & .325 \\
\hline Attitude Scale & $\begin{array}{l}\text { Experimental } \\
\text { Group } \\
\text { Control Group }\end{array}$ & 26 & 2.600 & .333 & -.730 & 53 & .469 \\
\hline Motivation Scale & $\begin{array}{l}\text { Experimental } \\
\text { Group } \\
\text { Control Group }\end{array}$ & 26 & 2.495 & .347 & .149 & 53 & .882 \\
\hline
\end{tabular}

Based on the results shown in Table 8, the difference between the posttest mean scores of the experimental and control groups regarding their academic achievement levels was significant $(\mathrm{n}=55)(\mathrm{t}=-2.23, \mathrm{p}<0.05)$. The mean score of the experimental group $(\mathrm{n}=26)$ was found to be ( $\bar{X}) 16.076$, and the mean score of the control group $(\mathrm{n}=29)$ was $(\bar{X}) 14.069$. The posttest mean score of the experimental group was found to be higher than the control group $(\bar{X}$ experimental $-\bar{X}_{\text {control }}=2.007$ ). Accordingly, the applied teaching method positively affected the academic achievement levels of the students in the experimental group. 
No significant difference was found between the posttest scores of the experimental and control groups regarding their basic skills $(\mathrm{t}=.994, \mathrm{p}>0.05)$ and science course-related attitudes $(\mathrm{t}=-.730, \mathrm{p}>0.05)$ and motivations $(\mathrm{t}=.149, \mathrm{p}>0.05)$.

\section{Discussion and Conclusion}

In the comparison of the experimental and control groups before the intervention applied in the experimental and control groups based on the pretest that was applied, no significant difference was found between the two groups regarding their academic achievement, basic skill, science course-related attitude and science course-related motivation scores. Accordingly, the two groups were initially homogenously distributed.

According to the results of the intragroup analyses conducted between the pretest and posttest scores of both groups, the two groups had significantly higher academic achievement levels in the posttest in comparison to the pretest. Still, the students in the experimental group had significantly higher achievement scores than those in the control group. These data revealed that the Web 2.0 animation-aided teaching method in the experimental group became more successful than the curriculum-based activities carried out in the control group. There are many studies where animations have been shown to increase academic success. The result of this study was consistent with those reported in similar studies in the literature (Çelen, Çelik and Seferoğlu, 2017; Daşdemir, 2006; Eryiğit, 2018; Göllü, 2019). However, this study aimed to reveal the effect of the animations prepared by the researcher using a Web 2.0 animation development tool.

The basic skill pretest and posttest scores were not significantly different in the experimental group. However, for the control group, the difference was significant, where the posttest scores were higher than the pretest scores regarding the basic skills test. While the difference of the scores obtained from the basic skills test was $\bar{X}_{\text {PostT }}-\bar{X}_{\text {PreT }}=1.11$ in the experimental group, this difference was calculated as $\bar{X}_{\text {PostT }}-\bar{X}_{\text {PreT }}=1.48$ in the control group. Although the posttest scores increased in the activities carried out in both the experimental and control groups, the increase in the experimental group was not statistically significant. This was an unexpected result since the activities performed in the control group were also conducted in the experimental group. Additionally, the topics presented in the experimental group were supported by animations created with a Web 2.0 animation development tool. The reason for this result to yield in the experimental and control groups may be latent reasons that may arise in the process such as the status of the respondents and by luck. This result was different from those reported in the studies by Daşdemir (2012). Daşdemir (2012) reached the conclusion that using animation in science courses contributes to development of basic skills.

No statistically significant difference was found between the pretest and posttest mean scores of the experimental and control groups regarding their attitudes and motivations towards the science course. Although the mean scores increased in favor of the posttests, neither of the two teaching methods applied provided a significant effect in increasing the students' science course-related attitudes and motivation. The reason for this may have been that development of attitude and motivation, which are affective characteristics, is difficult to change in a short time. The studies in the literature conducted by Türkan (2010), Yakışan (2008) and Bayram (2012) were consistent with the results of this study. In the literature, there are also studies that have concluded that the use of animations in science courses contributes to development of attitudes and motivations (Daşdemir, 2006; Eryiğit, 2018; Keskin, 2019). 
This study is significant due to the consideration that it will bring a different perspective in terms of materials used in science teaching. In this study, unlike other studies in the literature, the animations were prepared by the researcher using the PowToon animation tool.

While reviewing the literature, the effects of using Web 2.0 tools on teaching environments were examined. The use of Web 2.0 animation tools was preferred in this study, and the research was conducted in this direction. There are many studies investigating the effectiveness of animations. However, the fact that the teacher can customize the course material using Web 2.0 animation development tools is the innovation that this study will present. The study will contribute to the literature in terms of evaluating the effects of using animation-based web tools in learning environments.

By using Web 2.0 tools, teachers may indeed prepare materials suitable for their classes themselves. Thus, it becomes easier to prepare content suitable for the preparedness levels of students.

Except that by using Web 2.0 animation development tools, teachers may keep their course content up to date. They may provide an effective and entertaining learning environment where the desired message can be conveyed effectively eliminating boredom.

\section{Recommendations}

- By developing topics or courses aided by different Web 2.0 tools for classes on different levels and applying them for longer periods, the effects of Web 2.0 tools on the students' basic skills, science course attitudes and motivations may be investigated.

- New strategies and learning theories should be developed to be processed with the effective use and support of Web 2.0 tools.

- Peer learning studies, in which students who have sufficient knowledge and skills about web tools are included, and Web 2.0 applications are actively used, may be carried out.

- To promote active student participation in the designed animations, there should be activities such as questions and puzzles placed into the animation which students will answer.

\section{Note}

This study was created with the master's thesis of Mustafa Ziya UYSAL that was conducted under the consultancy of Prof. Barış ÇAYCI.

\section{References}

Aydoğdu, B. and Karakuş, F. (2015).The adaptation study to Turkish of basic process skills scale towards primary students. Mehmet Akif Ersoy University Journal of Education Faculty, 34(1), 105-131.

Bayram, K. (2012). The effect of using animation on the candidate teachers' academic achievements, attitudes and retention levels. (Unpublished Master Thesis). Necmettin Erbakan University, Konya.

Büyüköztürk, Ş., Çokluk, Ö. and Köklü, N. (2018). Statistics for the social sciences $\left(20^{\text {th }}\right.$ Edition). Ankara: Pegem Akademi publ. 
Creswell, J. (2017). Eğitim Araştırmaları [Educational research]. İstanbul: EDAM publ.

Çelik, A. and Seferoğlu, S. (2011, February). Turkish education system and PISA results. Academic İnformatics Conference, Malatya İnönü University. Abstract retrieved from:http://yunus.hacettepe.edu.tr/ sadi/yayin/AB11_Celen-Celik_Seferoglu_PISASonuclari.pdf

Çötok, A. N. (2006). The education phenomenon in the transition period from industry society to information society. (Unpublished Master Thesis). Sakarya University, Sakarya.

Daşdemir, İ. (2006). The effect of using animation on students' academic achievements and retentions in primary science course. (Unpublished Master Thesis). Atatürk University, Erzurum.

Daşdemir, İ. (2012). The effect of using animation on primary science and technology course students' academic achievement, retention of knowledge and scientific process skills. (Unpublished Doctoral Thesis). Atatürk University, Erzurum.

Deperlioğlu, Ö. and Köse, U. (2010, January). Effects of web 2.0 technologies on the education and an example learning experience. Academic Informatics Conference, Süleyman Demirel University Isparta. Abstract retrieved from: https://www.researchgate.net/publication/280230890_Web_20_teknolojilerinin_egiti m_uzerindeki_etkileri_ve_ornek_bir_ogrenme_yasantisi

DiNucci, D. (1999). Fragmented future. Print Magazine, 53 (4), 32. Retrieved from: http://darcyd.com/fragmented_future.pdf

Eryiğit, U. (2018). The effect of using animation on the academic success of students and their attitudes in sciences. (Unpublished Master Thesis). Mehmet Akif Ersoy University, Burdur.

Göllü, O. (2019). The effect of secondary school students on the academic achievements of using animation in materials and warm up unit. (Unpublished Master Thesis). Sütçü İmam University, Kahramanmaraş.

Jarrett, K. (2008). Interactivity is evil! A critical investigation of web 2.0 First Monday, 13 (3), 2-13. Retrieved from: https://firstmonday.org/article/view/2140/1947

Karasar, N. (2000). Bilimsel araştırma yöntemi [Scientific research method]. (10th edition). Ankara: Nobel Publ.

Keskin, D. (2019). The effects of the slowmotions designed in reproduction growth and development on plants and animals' unit toward 6th grade students' science and technology attitudes. (Unpublished Master Thesis). Aksaray University, Aksaray.

Özmen, F., Aküzüm, C., Sünkür, M. and Baysal, N. (2011, May). Functionality of social networks in educational settings. 6th International Advanced Technologies Symposium (IATS'11), Firat University, Elazığ.

Silva, J. M., Rahman, A. S., and El Saddik, A. (2008, January). Web 3.0: a vision for bridging the gap between real and virtual. Paper presented at the 1st ACM international workshop on Communicability design and evaluation in cultural and ecological multimedia system. Vancouver British Columbia, Canada.

Tabachnick, B. and Fidell L. (2013). Using Multivariate Statistics (sixth ed.). Pearson, Boston.

Turgut, M. F., Baykul Y. (2011) Ĕ̈itimde ölçme ve değerlendirme [Measurement and evaluation in education]. (2th edition). Ankara: Pegem Akademi publ.

Türkan, S. (2010). Research of the effects of the animation to the 7th grade students' achievements in teaching daily life electric subjects and their attitudes toward science and technology course. (Unpublished Master Thesis). Gazi University, Ankara. 
Uyanık, G. (2014). Examining the effectiveness of conceptual change approach in fourth grade primary school science and technology course. (Unpublished Doctoral Thesis). Gazi University, Ankara.

Yakışan, M. (2008). Effect of computer animations upon achievement attitude and misconceptions of biology education. (Unpublished Doctoral Thesis). Gazi University, Ankara. 